\title{
Mental health among displaced and non-displaced populations in Valledupar, Colombia: Do inequalities continue?
}

Sonia Diaz Monsalve ( $\sim$ sonia.diaz.monsalve@zmg.uni-freiburg.de)

Albert-Ludwigs-Universitat Freiburg https://orcid.org/0000-0002-2308-525X

Angélica María Vargas-Monroy

Pontificia Universidad Javeriana

Jannethe Esmeral Ariza

Secretaria de Salud Departamental del Cesar

Ana Maria Oñate Cuello

Secretaria de Salud Municipal de Valledupar

Ana Rosa Ropero Vera

Secretaria de Salud Departamental del Cesar

Juan Carlos Bermudez Cuello

Secretaria de Salud Municipal de Valledupar

Lina Arzuaga Zuleta

Secretaria de Salud Departamental del Cesar

Andrés Felipe Cubillos Novella

Pontificia Universidad Javeriana

Enrique Peñaloza Quintero

Pontificia Universidad Javeriana

Yesika Natali Fernández Ortiz

Pontificia Universidad Javeriana

Axel Kroeger

Albert-Ludwigs-Universitat Freiburg

Research article

Keywords: Mental health, displaced populations, inequity, Colombia

Posted Date: January 20th, 2021

DOI: https://doi.org/10.21203/rs.3.rs-27875/v3 
License: (c) (i) This work is licensed under a Creative Commons Attribution 4.0 International License. Read Full License 


\section{Abstract}

Background: During the long-lasting civil war in Colombia, the year 2002 marked a peak of violent activities displacing thousands of people mainly from rural to urban areas, causing social disruption and prolonged poverty. In 2015, the Colombian national survey on mental health included a first overview of mental health problems of victimized families. The here presented study aimed at analysing the traumatic experience many years ago on the current psycho-emotional status of displaced families as well as the ongoing inequalities regarding displaced and non-displaced populations in one of the most affected areas by the armed conflict.

Methods: An interview survey was conducted among 211 displaced families and 181 non-displaced families in 2 adjacent compounds with several five-storey buildings in the outskirts of Valledupar, the capital of Cesar State in Colombia. The questionnaires were developed together with and applied by staff of the health and social services of the departmental secretary of health. The 15 interviewers conducted additionally in-depth interviews and participant observations.

Results: The living conditions of the displaced community were precarious (lack of security, noise, drug trafficking, poor public transport). As a consequence of the past traumatic events about 16 to 18 years ago and current difficult living conditions, psycho-emotional problems were more frequent among the displaced compared to the non-displaced neighbourhood. The displaced had experienced more violent acts (intended murder, threat, murder of a family member and kidnapping) and had subsequently a larger number of emotional symptoms (fright, headache, nervousness, depression, sleeplessness). Other stress factors like economic problems, severe disease or death of family members and unemployment prevailed among displaced persons compared to the non-displaced. The non-displaced lived in a more protected environment with less exposure to violence and stress, although belonging to a similarly low socioeconomic stratum. Those previously displaced respondents now living in the non-displaced community still suffered similar emotional symptoms as the displaced respondents living in the displaced community. It is recommended to take measures for a better protection of the displaced community, improve their access to the job market, offer different leisure activities (sports club, art, women's club) and facilitate public transport.

\section{Background}

\section{The international context}

Worldwide there are over 50.8 million people living in internal displacement for 2019 [1], most of them has been displaced due to conflict, violence and disasters. Forced displacement associated with conflicts seems to have a profound health and social impact on internally displaced persons (IDPs) [2,3], including acute and long-terms effects on mental health [4]. Many forced IDPs lack legal status and psychosocial protection as they are not covered by international refugee laws. They are displaced within nation boundaries where are commonly marginalized [5]. It has been shown that IDPs are more likely to 
experience poorer mental health indices than refugees or asylum seekers [6-9]. However, little attention has been paid to their mental health and well-being, and their needs are poorly supported by relief agencies [10].

Research suggests that IDPs are a high-risk group for mental health disorders [11,12]. Studies among IDPs report widely varying estimates of mental health disorders, in particular depression, post-traumatic stress disorder (PTSD) and other anxiety disorders linked to conflict [13-17]. Many displaced people have undergone traumatic episodes before and during their displacement and had to cope with long displacement periods with social and economic adversities [18], making them vulnerable for psychological disorders, particularly PTSD [19]. Porter \& Haslam (2005) suggest that mental disorders may persist in IDPs for many years and may even increase over time [8]. This increased risk may also be related -among others- to post-migration socio-economic factors $[8,20]$. Risk factors include female gender, household roles, older age, food insecurity, continued trauma exposure, and poor economic situation $[8,21,22]$. However, limited evidence is available on how mental health disorders varies within a post-conflict setting following prolonged periods of displacement experiences. Thus, understanding the unique mental health status and possible risk factors for specific populations with long-term displacement is crucial for providing adequate care.

\section{The Colombian context}

Civil war is a sad reality of many countries in our contemporary world and Colombia is a prominent example among them. Colombia with a total population of roughly 50 million inhabitants has suffered an armed conflict among different interest groups for several decades, which partially ended in 2016 with the peace treaty of the government with FARC (Fuerzas Armadas Revolucionarias de Colombia, Colombian Revolutionary Armed Forces), one of the major guerrilla groups. More than five million Colombian citizens have suffered violence and internal displacement during this time affecting their mental health and well-being and creating high levels of headache, sadness, nervousness, suicidal attempts and depression [23]. The situational analysis of the health situation in Colombia has shown that the internal displacement has generated vulnerability and affected the physical and even more the mental health of the families involved [24]. According to the national Programme for Attending Psychosocial and Integral Health among Victims (PAPSIVI) the armed conflict has generated a deterioration of living conditions among these groups creating distrust, insecurity and fear [25]. Research also demonstrated that Colombian IDPs present high prevalence of depression, anxiety, PTSD, and substance use disorders [26-28], especially women [26,29]. Although, there is an increasing research interest in the health of conflict-affected populations in Colombia, there is still a scarcity of information on mental health issues in IDPs many years after the forced displacement.

According to the Central Register of Victims, the State of Cesar is one of the most affected States (departamentos) by the armed conflict in the country [30]. According to this source, the State has more than 300,000 victims, $85 \%$ of them being displaced. In Valledupar, the capital of the State, 132.294 victims were registered in July 2018 mainly living in neighbourhoods with high insecurity levels and 
crime. In spite of these problems, no detailed information is available which could help to plan a better future for these communities and the information from the National Mental Health Survey is much to general to provide concrete guidance for what needs to be done. Health and social workers operating in these neighbourhoods are aware of problems but do not have concrete information about the real dimension of human suffering which can directly lead to action.

In order to understand the magnitude (prevalence) of the psycho-social challenges among displaced families or those subject to other forms of violence by the armed conflict, the here presented study was set up jointly by the State Health Services in Cesar and universities in Colombia (Instituto de Salud Pública de la Pontificia Universidad Javeriana) and Germany (Freiburg University, Centre for Medicine and Society) supported by the German Academic Exchange Service (DAAD). The objectives were i) to quantify the prevalence of mental health issues (mainly emotional distress) among displaced and victimised persons in comparison with non-displaced persons of a similar socio-economic status living in the same environment and ii) to analyse if the cause of the expected increased distress among the displaced is more due to the traumatic experience many years ago or to the current precarious living conditions of the displaced. The overall aim was to provide recommendations for designing programmes for improving the situation.

\section{Methods}

\section{Study communities}

Both displaced and non-displaced study communities were located next to each other in a suburb of Valledupar. The displaced families were all registered as victims of the armed conflict with RUV.

Displaced community: The neighbourhood of Hernando Marín was constructed in the outskirts of Valledupar by the national Government as part of a social programme to provide shelter to poor displaced families (belonging to stratum 1 to 2 in the Colombian socio-economic classification system where stratum 5 represents the highest level). Six blocks of five-storey buildings with a total of 1900 departments were built, each apartment having a surface area of $45.6 \mathrm{~m} 2$ (see Fig. 1). The families can live there for free and have only to pay for water, electricity, gas, and administration.

Non-displaced community: The neighbourhood Leandro Diaz was part of a governmental housing programme for employees of the lower socio-economic level (stratum 2). It has three blocks, each with six five-storey buildings, in total 1300 apartments. A fence secures the buildings and a security guard controls the entrance (see Fig. 1). The families must pay a subsidized rent plus expenses for basic services (water, electricity, gas, administration).

\section{Method of approach}

A mixed method approach was applied with quantitative elements (questionnaire survey) and qualitative elements (observational study with in-depth interviews). 


\section{Questionnaire survey}

The interview survey was conducted among 211 displaced families and 181 non-displaced families living in two adjacent compounds. The survey was only applied to adults who provided information related to the purpose of this study. No child or adolescent below the age of 18 was interviewed in this study. Special care was devoted in the interviewer training to the emotional part of an interview setting. Our 15 interviewers (14 of them women) were familiar with social and mental health challenges of poor families. The way of showing compassion and understanding was discussed in the training and practices. The interviews should be conducted in a quiet place for which reason quiet afternoon hours were preferred for the interviews. Frequently interviewers had to come back the following day when the levels of noise were lower. The questionnaires were developed together with 15 staff members of the health and social services of the State Secretary of Health. The questions were a selection of the most relevant questions used in the national survey on mental health [23], except for the introductory questions for the characterization of the study populations. The ENSM included nationally and internationally validated instruments such as la Gran Encuesta Integrada de Hogares 2013-the Great Integrated Household Survey 2013 [31]; the Self Report Questionnaire (SRQ-)[32] and the Family APGAR [33] of which only< the SRQ was relevant for our study. The selected groups of questions were directly related to our specific study topic such as personal and family experience with violence, mental health symptoms and disorders and mental health services. 15 staff members of the health and social services of the State Secretary of Health were trained by our research team in a 3-days workshop which included theoretical and practical components as well as a field visit.

\section{Sample size calculation and sampling procedure}

The sample size was calculated using data from the national mental health survey on the difference of proportions of major mental health issues in displaced families compared to the non-displaced. With a confidence level of $95 \%$, a power of $80 \%$ and a cumulative prevalence of major emotional problems among the displaced versus non-displaced populations of $55 \%$ versus $30 \%$ respectively, a minimum simple size of 170 families per study arm was calculated, but finally 211 displaced and 181 nondisplaced families were interviewed. Using systematic sampling with a random start (using a die), the sampling interval in the displaced families was nine (every ninth family to be interviewed) and in nondisplaced it was eight (every eighth family to be interviewed).

\section{Survey procedures and non-response}

After pre-testing the questionnaire, the leaders of both communities were informed and consulted in separate meetings and their consent was obtained as well as their willingness to inform the community. Then the 15 interviewers (the same staff members as mentioned above) used mainly their free weekends or afternoon hours to conduct the interviews in the assigned buildings. The team leader conducted several control interviews and checked the sampling interval. The non-response rate (rejection to participate or absence) was $6 \%$ among the displaced sample and $8 \%$ in the non-displaced sample. 
During and after the interview additional in-depth interviews were done with the interview partners and the same interviewers conducted participant observations. They were recorded in a field diary and later on ordered in thematic topics and analysed. When reading the interviewer field diaries and listening to the interviewers ' passionate discussions regarding the translation of research findings into policy and practice, we as a research team were confident that we had selected the right interviewers who had been able to get reliable information from our study populations.

\section{Data management and analysis}

Interview answers were entered into the computer and analysed using Excel and SPSS software. Results were tabulated and different bar charts developed. A comparative analysis examining the sample characteristics and metal health issues of the two study communities was conducted.

\section{Results}

\section{The study populations}

In the displaced community, 211 families (845 individuals) were interviewed and in the non-displaced population 181 families (732 individuals), showing four persons per family in both groups. The direct respondents to the interview were in both communities mainly women at the age of 30 to 50 years, almost all of them with school education. However, in the displaced community, 9.6\% (81) did not comply with the definition of displacement (i.e. were not registered with RUV) and in the non-displaced community, $12.4 \%$ (91) of families were in fact displaced according to the registration with RUV (Central Colombian Register for Victims).

The demographic characteristics of both communities were similar: slight excess of females (female to male ratio 1.04 in the displaced community and 1.1 in the non-displaced) and slight excess of young adults among the displaced compared to the non-displaced (38.7\% of all ages versus $31.6 \%, p=0.018)$. The proportion of children $<15$ years old was higher among the displaced compared to the non-displaced. With respect to ethnicity, in both groups the mestizo-population (ethnic mixture) was predominant (53.3\% of all families) while the afro-descendants and indigenous people had suffered more frequently from displacement: $28.0 \%$ afro-descendants among the displaced families and $20.4 \%$ among the nondisplaced, $5.7 \%$ of indigenous people among the displaced and $2.2 \%$ among non-displaced $(p=0.052)$. The educational level of persons above 12 years of age including qualified technicians was clearly higher in the non-displaced group ( $35.6 \%$ of all educational levels) compared to the displaced group (only $15.7 \%$ of all; $p=0.000$ ).

\section{History of displacement}

The peak of the violence in Colombia occurred from 2002 to 2004, which means about 18 years before our survey when our mostly female respondents were about 20 years old. Therefore $55.5 \%$ of the 
displaced families reported that the event of displacement has happened between 16 to 20 years ago. Only a smaller proportion (19.0\%) had been displaced 11 to 15 years ago and only $9.5 \%$ during the preceding 10 years. However, the in-depth interviews showed that the traumatic experience of displacement and victimization had still a profound emotional effect on the displaced in present times (tears, profound breathing, lifting the voice) and that the fear of going back and receiving bad News from their place of origin kept the memory of those days of life.

\section{Peoples 'perception of the current situation (qualitative study)}

In the displaced community, the government subsidizes the apartments and the inhabitants did not have to pay a rent. However, there was a continuous feeling of insecurity -as mentioned by most respondentsdue to the open access to the premises, and the existence of gangs of young adults as well as of drug users. The interviewers could witness this; particularly when they arrived in the late afternoon, they saw groups of youngsters and perceived the smell of marihuana. Another problem was the noise which was always present, either loud music or intra-familiar fights or aggression between families. The elected community leaders did not seem to have much authority, as they did not want to accompany the interviewers (mostly females) or introduce them to the families. Taxi drivers could hardly be convinced to enter the compound and bring the interviewers to the buildings because of the bad access road and the feeling of insecurity. In general, families were happy to answer the interview questions.

In the adjacent buildings of the non-displaced community, the situation was different. The flats were partially subsidized by the government, but the residents had to pay a rent. The residential area was closed for outsiders by a fence and a special permission was required to enter. There was an administrator of the compound who looked over the security and order and controlled entering unknown people. However, the risk of leaving the compound and being attacked on the street was also mentioned. Although the families belonged to the second lowest socio-economic stratum, they felt superior to the adjacent displaced community. Some of them did not want to answer the interview questions due to mistrust.

\section{Experience with violence}

When asked for their exposure to violence, significantly more displaced families had experienced such events $(n=64.0 \%)$ compared to non-displaced families $(n=25.4 \% ; p=0.000)$ (Fig. 2, table 2). The responses show that in all categories (intended murder, theft, threat, murder of a family member, kidnapping and sexual violence) the displaced families had to suffer much more frequently than the nondisplaced ones. Also, the non-displaced had suffered, although to a less extent, particularly of theft and to less extent of intended murder. Once a violent event has happened, both groups suffered equally of emotional disturbance. 
Table 2 Victims of violence in displaced and non-displaced families (means and Cls)

\begin{tabular}{|l|c|c|c|c|}
\hline Displaced or & Victims of violence & \multirow{2}{*}{ Percentage } & \multicolumn{2}{|c|}{$95 \% \mathbf{~ C l}$} \\
\cline { 3 - 5 } non-displaced & & & Lower Cl & Upper Cl \\
\hline \multirow{2}{*}{ Displaced } & Yes & 64,0 & 57,5 & 70,46 \\
\cline { 2 - 5 } & No & 36,0 & 29,5 & 42,5 \\
\hline \multirow{2}{*}{ Non-displaced } & Yes & 25,4 & 19,1 & 31,8 \\
\cline { 2 - 5 } & No & 74,6 & 68,2 & 80,9 \\
\hline \multirow{2}{*}{ Total } & Yes & 46,2 & 41,2 & 51,1 \\
\cline { 2 - 5 } & No & 53,8 & 48,9 & 58,7 \\
\hline
\end{tabular}

In addition, the intra-familiar violence was clearly more frequent in the displaced community (victims of insults, physical aggression, and armed attacks) compared to the non-displaced community $(p=0.001$, 0.035 , and 0.001 , respectively; Fig. 3, table 3). Other causes of human suffering were important life or vital events such as economic problems (affecting $72.5 \%$ of the displaced families compared to $43.1 \%$ of the non-displaced; $p=0.000$ ). Also severe disease or death of a family member as well as unemployment and severe health problems were more frequent among the displaced families compared to the nondisplaced ones (Fig. 4, table 4).

Table 3 Intra-family violence among displaced and non-displaced families (means and Cls)

\begin{tabular}{|l|l|c|c|c|}
\hline Type of intra-family & Displaced or & \multirow{2}{*}{ Percentage } & \multicolumn{2}{|c|}{$\mathbf{9 5 \%} \mathbf{C l}$} \\
\cline { 4 - 5 } violence & non-displaced & & Lower $\mathbf{C l}$ & Upper Cl \\
\hline \multirow{3}{*}{$\begin{array}{l}\text { Physical assault (push, } \\
\text { kick, bite, punch) }\end{array}$} & Displaced & 16,6 & 11,6 & 21,6 \\
\cline { 2 - 5 } & Non-displaced & 8,8 & 4,7 & 13,0 \\
\cline { 2 - 5 } & Total & 13,0 & 9,7 & 16,3 \\
\hline \multirow{2}{*}{$\begin{array}{l}\text { Attack by weapon, } \\
\text { strangulation, or burn }\end{array}$} & Displaced & 15,6 & 10,7 & 20,5 \\
\cline { 2 - 5 } & Non-displaced & 4,4 & 1,4 & 7,4 \\
\cline { 2 - 5 } & Total & 10,5 & 7,4 & 13,5 \\
\hline \multirow{3}{*}{$\begin{array}{l}\text { Sexual abuse at home } \\
\text { Insults, threats, }\end{array}$} & Displaced & 4,3 & 1,5 & 7,0 \\
\cline { 2 - 5 } & Non-displaced & 5,0 & 1,8 & 8,1 \\
\cline { 2 - 5 } & Total & 4,6 & 2,5 & 6,7 \\
\cline { 2 - 5 } & Displaced & 23,7 & 18,0 & 29,4 \\
\cline { 2 - 5 } & Non-displaced & 11,6 & 6,9 & 16,3 \\
\cline { 2 - 5 } & Total & 18,1 & 14,3 & 21,9 \\
\hline
\end{tabular}


Table 4 Life events among displaced and non-displaced families (means and Cls)

\begin{tabular}{|c|c|c|c|c|}
\hline \multirow[t]{2}{*}{ Life events } & \multirow{2}{*}{$\begin{array}{l}\text { Displaced or } \\
\text { non-displaced }\end{array}$} & \multirow[t]{2}{*}{ Percentage } & \multicolumn{2}{|c|}{$95 \% \mathrm{Cl}$} \\
\hline & & & Lower $\mathrm{Cl}$ & Upper Cl \\
\hline \multirow{3}{*}{$\begin{array}{l}\text { Have been divorced or } \\
\text { separated }\end{array}$} & Displaced & 37,0 & 30,5 & 43,5 \\
\hline & Non-displaced & 37,0 & 30,0 & 44,1 \\
\hline & Total & 37,0 & 32,2 & 41,8 \\
\hline \multirow[t]{3}{*}{ Have lost a job or retired } & Displaced & 36,5 & 30,0 & 43,0 \\
\hline & Non-displaced & 23,8 & 17,6 & 30,0 \\
\hline & Total & 30,6 & 26,1 & 35,2 \\
\hline \multirow{3}{*}{$\begin{array}{l}\text { Have had serious health } \\
\text { problems }\end{array}$} & Displaced & 33,6 & 27,3 & 40,0 \\
\hline & Non-displaced & 18,2 & 12,6 & 23,9 \\
\hline & Total & 26,5 & 22,2 & 30,9 \\
\hline \multirow{3}{*}{$\begin{array}{l}\text { Have had serious financial } \\
\text { problems }\end{array}$} & Displaced & 72,5 & 66,5 & 78,5 \\
\hline & Non-displaced & 43,1 & 35,9 & 50,3 \\
\hline & Total & 58,9 & 54,1 & 63,8 \\
\hline \multirow{3}{*}{$\begin{array}{l}\text { Spouse, partner, partner } \\
\text { has died }\end{array}$} & Displaced & 18,0 & 12,8 & 23,2 \\
\hline & Non-displaced & 6,1 & 2,6 & 9,6 \\
\hline & Total & 12,5 & 9,2 & 15,8 \\
\hline \multirow{3}{*}{$\begin{array}{l}\text { Illness or death of a family } \\
\text { member or someone very } \\
\text { close }\end{array}$} & Displaced & 67,8 & 61,5 & 74,1 \\
\hline & Non-displaced & 51,9 & 44,7 & 59,2 \\
\hline & Total & 60,5 & 55,6 & 65,3 \\
\hline \multirow{3}{*}{$\begin{array}{l}\text { Important positive change } \\
\text { in life }\end{array}$} & Displaced & 54,5 & 47,8 & 61,2 \\
\hline & Non-displaced & 58,0 & 50,8 & 65,2 \\
\hline & Total & 56,1 & 51,2 & 61,0 \\
\hline
\end{tabular}

Current psycho-emotional status of displaced and non-displaced respondents (Self Reporting Questionnaire, SRQ)

There were 22 different emotional symptoms mentioned: frequent headaches, loss of appetite, sleeplessness, fright, trembling of hands, tension/nervousness, mal-digestion, lack of clear thinking, sadness, does not enjoy daily activities, difficulty to take decisions, difficulty to work, incapable of doing something useful, loss of interest, feels to be useless, suicidal thoughts, feels tired all the time, has unpleasant feelings in the stomach, gets easily tired, feels that somebody has tried to wound her, feels that she is more important than other people think.

$46.4 \%$ of the displaced interviewees and only $20.4 \%$ of the non-displaced suffered seven or more symptoms $(p=0.000)$. Only $6.6 \%$ of the displaced had no symptom at all while among the non-displaced interviewees this was $20.4 \%$ ( $p=0.000$, Fig. 5 , table 5). 
Table 5 Number of emotional symptoms reported in the SRQ by formerly displaced and nondisplaced individuals (means and Cls)

\begin{tabular}{|l|l|c|c|c|}
\hline Number of emotional & Displaced or & Percentage & \multicolumn{2}{|c|}{$95 \%$ Cl } \\
\cline { 4 - 5 } symptoms reported in the SRQ & non-displaced & & Lower Cl & Upper Cl \\
\hline \multirow{4}{*}{ No symptoms } & Displaced & 6,6 & 3,3 & 10,0 \\
\cline { 2 - 5 } & Non-displaced & 20,4 & 14,6 & 26,3 \\
\cline { 2 - 5 } & Total & 13,0 & 9,7 & 16,3 \\
\hline \multirow{3}{*}{ to 6 symptoms } & Displaced & 46,9 & 40,2 & 53,7 \\
\cline { 2 - 5 } & Non-displaced & 59,1 & 52,0 & 66,3 \\
\cline { 2 - 5 } & Total & 52,6 & 47,6 & 57,5 \\
\hline \multirow{3}{*}{ or more symptoms } & Displaced & 46,4 & 39,7 & 53,2 \\
\cline { 2 - 5 } & Non-displaced & 20,4 & 14,6 & 26,3 \\
\cline { 2 - 5 } & Total & 34,4 & 29,7 & 39,1 \\
\hline
\end{tabular}

More than half of the 211 displaced respondents felt symptoms like "get easily frightened" (62.1\%) and "frequent headache" (59.7\%), "feels nervous or tense" (54.0\%), all of them being much rarer than among the 181 non-displaced respondents (35.9\%, 43.6\% and 30.4\% respectively; $p=0.000,0.001$ and 0.000 respectively). Other frequent emotional disorders among the displaced interviewees was "feels depressed" (47.9\%), "cannot sleep" (43.6\%) or "cannot think well" (40.8\%) in contrast to the non-displaced participants $(28.2 \%, 22.1 \%$ and $32.0 \%$ respectively; $p=0.000,0.000$ and 0.074 respectively). There were three additional questions on psychotic symptoms ("hears strange voices", "has strange interferences in her thoughts", "has epileptic seizures") but these were rare in both groups although marginally more frequent among the displaced respondents.

\section{Current psycho-emotional status of displaced respondents living in the non-displaced community}

This analysis was done to better understand if the emotional problems among displaced respondents are more due to the displacement or due to the current living conditions, $40.9 \%$ of the 91 respondents belonging to the "displaced living among the non-displaced" reported more than seven symptoms in the SRQ and showed a pattern of emotional distress similar to the displaced group rather than to the nondisplaced suggesting that the traumatic experience of the armed conflict with displacement and victimization long ago still impacts on the emotional status of displaced individuals and their families.

\section{Use of mental health services}

Mental health services in local hospitals and ambulatory care were equally available for the displaced and non-displaced persons. However, they were rarely used during the preceding 12 months, both by displaced families (16.6\%) and even less by non-displaced families (6.1\%; $p=0.000)$. Hospitalizations for mental health problems "once in their lives" were rare exceptions (4.7\% among the displaced and $0.6 \%$ among the non-displaced; $p=0.012$ ) keeping in mind that the relative frequency of mental health issues 
was higher among the displaced compared to the non-displaced populations. The main reason for not using mental health services during the last 12 months were "was not necessary" (39.1\% among the displaced and $71.6 \%$ among the non-displaced; $p=0.000$ ). Other major reasons for not attending mental health services particularly among the displaced families were, service far away, no time, no money, unawareness of my rights, bureaucratic hurdles, distrust.

Most patients attending mental health services went there 3 times or less $(12.3 \%$ among displaced persons and $5.0 \%$ among non-displaced; $\mathrm{p}=0.001$ ). Patients in both groups went for treatment mainly to hospitals or clinics (56.3\% both groups), but some of them to pharmacies (mainly the non-displaced) or to friends and family members including alternative medicine. Additional consultations for mental health problems were mainly sought by non-displaced patients (28.9\%) and less by the displaced $(17.8 \%$; $p=0.157)$. The treatment costs for displaced patients were mainly borne by the subsidized insurance companies for the displaced patients $(48.9 \%)$ while the treatment of non-displaced patients was mainly financed by the pre-paid insurance companies $(21.1 \%)$ and often through out-of-pocket payment.

\section{Discussion}

The civil war in Colombia - as a prominent example of similar conflicts in our current world- with its peak of violence in the early years of our century is officially over with the peace treaty signed by the government and the most important rebel group FARC in 2016. At the climax of the conflict around 2002, many particularly rural families had to leave their homes and farms due to the threat by major parties of the armed conflict, mainly paramilitary groups in Cesar State. They generally fled to the capital of their State (department) where they finally found a place where to stay, often in a multi-family building provided by the government.

The national survey on mental health in Colombia [23] had shown an overall picture of the mental health status of the nation, distinguishing in some parts of the report between the general and the displaced population. Some but in general not very strong differences have been elucidated between the two groups but naturally at a "macro" level and without adjusting for socio-economic differences. Our study was able to give more detailed insights into the mental health status of two populations with a similar socio-economic status living close to each other but with the distinctive characteristic to belong to the displaced community as against the non-displaced community. Although the event of displacement has happened almost two decades ago, there were still important differences regarding mental health status and associated factors. These will be summarized in the following:

\section{Context and circumstances}

Displaced and non-displaced belonged to the lower socio-economic population strata so that in our comparative analysis "socio-economic status" may not be an important confounding variable (although persons older than 12 years had in the non-displaced population 2.3 times more frequently a secondary education compared with the displaced one). 
The main traumatizing event (displacement or another violent act) occurred 16 to 20 years before the study but had, according to the in-depth interviews among the displaced a long lasting effect on peoples emotional status fuelled by the impossibility to return to their rural homes because of the continuing insecurity. This is in line with the literature on post-traumatic stress disorder (PTSD) in displaced people by war $[34,35]$. The proportionally most affected groups were Afro-descendants and indigenous people (1.4 times and 3 times higher proportion Afro-Descendant and Indigenous descendants in the displaced compared to the non-displaced population).

Mental health status (outcome variable)

Significant differences between displaced and non-displaced families were:

- Currently more frequent emotional problems among displaced persons: higher number of symptoms, particularly frequent being fear, headache, and nervousness but also sleeplessness, problems to think with clarity and other depression-like symptoms

- The use of mental health services (mainly hospitals and clinics) was slightly higher by displaced than by non-displaced families (16.6\% versus $6.1 \%$ ) but did not reflect the much higher disease burden in the displaced community

\section{Determinants}

Experience of violence and other stress factor:

- More family members in the displaced community had experienced some form of violence $(64.0 \%)$ compared to the non-displaced community (25.4\%)

- Different forms of violence were more frequently reported by displaced families such as intended murder, threat, murder of a family member and kidnapping (NB. Questions on alcohol or substance abuse could not be asked, as they were perceived to be insensitive according to the pilot tests).

- Threatening life events as stress factors were more frequent in the displaced community: economic problems, severe disease or death of family members, unemployment, or severe diseases

Living conditions of the displaced community showed a number of stress factors:

- Open access to the premises allowing anybody to enter

- Weak leaders lacking authority

- Youth gangs often involved in drug trade or drug use

- Frequent unemployment

- Noisy neighbours (music, aggressions)

- Poor access road and poor connection with public transport

In contrast, the non-displaced community could live more in peace: 
- Closed and protected premises

- Strong authority controlling the access and order

- Better maintenance of the buildings

- Higher employment rates of both men and women

Other challenges for the non-displaced community were:

- Poor access road and poor connection with public transport

- Mistrust and social distancing from the neighbouring displaced community

- Fear of being attacked on the access road

In view of these determinants, it is not surprising that the displaced community living under precarious circumstances continues to be exposed to elevated mental health risks [18]. Additional factors such as the presence of gestational diabetes mellitus and other chronic diseases may worsen the mental health of those displaced populations as well as the lack of physical activity [36,37]. In contrast, the neighbouring non-displaced population can enjoy some basic commodities such as physical protection by a fence, a strong authority that is able to keep order, better maintenance of the building. However, the previous trauma of displacement seems also to persist among displaced families living in the more protected environment of non-displaced families as $40.9 \%$ of the individuals interviewed suffered from more than seven emotional symptoms -which is similar to the displaced respondents living in an unsafer environment (46.4\% with more than seven symptoms). This long term persistence of mental health issues after displacement has also been observed in Sri Lanka and Germany $[4,34,35]$. The low use of mental health services in our study compared with the national average (33\%) [38] confirms that vulnerable groups do not use them as much as they could and that cultural barriers are important. The main reason for not using mental health services was "not necessary" (39.1\% among the displaced and $71.6 \%$ among the non-displaced); this is consistent with the national survey where $47 \%$ to $56 \%$ of people with mental health issues considered that they did not need any consultation [23]. Attitudinal barriers towards resorting to mental health services have been frequently associated with the stigma generated by mental illness $[39,40]$.

\section{Recommendations}

Recommendations for the improvement of the living conditions particularly of the displaced population were developed by the State public health and social services based on the findings of the study. To these belong:

Increase security: Protective fence around the buildings of the displaced community; security guards (watchmen), promote a police station in the area

Reduce violence: Provide opportunities for sport, artwork, dancing, youth clubs, women's ' clubs 
Promote advanced education and employment: Provide incentives for entering higher education; encourage reading competition for children or storytelling for adults

Offer training on productive work (urban gardening, preparation of food, bakery etc.) to complement the family income.

Strengthen primary mental care in the community through psychologists and social workers in order to overcome the traumatic experiences of the past and face the problems of the current conditions (also recommended by Anaya Mercado and Romero Perez (2019) [41].

Other recommendations include:

Special effort to involve those committing violent acts in community activities

Repeat the survey after 3 years to see if changes have taken place.

\section{Limitations of the study}

Mental health questions are sensitive and special care must be applied regarding the wording of the questions, interviewer behaviour and interview setting in order to get reliable answers. The 2015 National Mental Health Survey from where the questions were taken has been carefully validated and previously adjusted to current social and economic conditions in the country [42]. In order to get information on the most prevalent psycho-emotional problems among our study groups, the Self Report Questionnaire by Beusenberg and Orley (1994) as an internationally renowned instrument was applied [32]. Previous studies have confirmed the potential of this instrument for the screening of psychological distress in poor settings [43-45].

The majority of respondents was happy to answer the interview questions, but there was a small number of families who did not want to participate or were absent during the interview. Some response bias was probably due to mistrust and fear. Other contextual factors before and during the displacement process including disruption of social networks- could not be evaluated in depth. However, in spite of these limitations we are confident that our study results reflect the reality of previously traumatized people living in quite precarious circumstances compared to others who did not have such a traumatic experience and can live in a more peaceful environment.

Limitations regarding our second objective (to better understand if the distress of displaced people is mainly due to their traumatic experiences in the past or to their current precarious living conditions) were more serious as the multiple factors influencing over the years the displaced families could not be sorted out retrospectively. However, the fact that those displaced respondents now living in the safer environment of the non-displaced community suffered from a similar distress as the displaced living in the insecure environment of the displaced community is a strong indicator reconfirming what has been observed in the in-depth interviews and reported in the literature (see above), that displaced individuals and families continue to suffer from their traumatic past. 


\section{Conclusions}

Sixteen to eighteen years after the peak of violence and displacement in Colombia, the victims are still suffering mental hardships (compared to non-victimized persons) which adds to their current precarious living conditions and requires new policies and programs to alleviate human suffering of vulnerable population groups.

\section{Abbreviations}

PAPSIVI: Program for Attending Psychosocial and Integral Health among Victims

ENSM: Encuesta Nacional de Salud Mental (National Mental Health Survey)

FARC: Fuerzas Armadas Revolucionarias de Colombia (Colombian Revolutionary Armed Forces)

RUV: Registro único de víctimas (Central Colombian Register for Victims)

PAGEL: Partnerships for the Health Sector in Developing Countries

DAAD: The German Academic Exchange Service

\section{Declarations}

\section{Ethics approval and consent to participate}

The interviews were initiated by a standardized description of the aims of the study, the institutions involved, the anonymity (no names were recorded), the right to stop at any time or to skip questions without any harm. No child or adolescent below the age of 18 was interviewed in this study. The consent was obtained verbally as under the given circumstances a written consent was not possible and not recommended by the community leaders. The procedure was checked by the supervisor and the consent to participate statement and ethical considerations were approved by the ethical committee of Pontificia Javeriana University. The ethical committees of Pontificia Javeriana University and Freiburg University approved the project on 07.03.2018 stating that the approval was based on "the pertinence of the investigation, the methodological rigor, its scientific quality, the coherence and adequacy of the proposed budget and the fulfilment of scientific, technical and ethical norms". The local health authorities accepted the approvals after a detailed presentation of the study.

Consent for publication

Not applicable

Availability of data and materials 
The datasets used and/or analysed during the current study are available from the corresponding author on reasonable request.

\section{Competing interests}

The authors declare that they have no competing interests.

\section{Funding}

Supervision travels by SDM and AK and the transport of the interviewers to the study neighbourhoods was financed by PAGEL programme.

The article processing charge was funded by the German Research Foundation (DFG) and the University of Freiburg in the funding programme Open Access Publishing.

\section{Author's contributions}

SDM, AMV, JEA, YNF and AK designed the study, did the interviewer training, and drafted the paper. All authors read and approved the study and the procedures. AMV, YNF, EPQ and AFCN prepared the submission to the ethical committee and prepared the logistics. JEA, AMO, ARRV, JCBC, LAZ prepared the field study, contacted the local leaders, organized the logistics. All authors read and commented on the draft paper and approved the final version

\section{Acknowledgements}

The German Academic Exchange Service (DAAD) in the context of the PAGEL programme facilitated this work. We are grateful to our co-interviewers for their patience and excellent work under difficult circumstances, particularly to Electa de Jesús Arzuaga Villero, Cecilia Flórez Sanchez, Yusleydis Gutiérrez Ospino, Sunilda María López Blanco, Yarima Vanessa Martínez Castilla, Olga Beatriz Ochoa Díaz, Martha Leonor Romero Orozco, Yerlis Saenz Arias, Nora Inmaculada Santos and Zuleima María Billa Jimenez. We thank Freiburg University for supporting the publication of this study and to Maria Angelica Carrillo for revising the manuscript and providing most valuable advice. We are particularly obliged to all our respondents who took the time and had the courage to answer our questions.

\section{References}

1. IDMC Internal Displacement Monitoring Center: Displacement data 2019. www.internaldisplacement.org. Accessed 28 Dec 2020.

2. Mooney E. The concept of internal displacement and the case for internally displaced persons as a category of concern. Refugee Survey Quarterly. 2005; 24(3):9-26.

3. Heudtlass P, Speybroeck N, Guha-Sapir D. Excess mortality in refugees, internally displaced persons and resident populations in complex humanitarian emergencies (1998-2012) - insights from operational data. Conflict and Health. 2016;10:15. 
4. Kuwert P, Brähler E, Glaesmer H, Freyberger HJ, Decker O. Impact of forced displacement during World War II on the present-day mental health of the elderly: a population-based study. Int Psychogeriatr. 2009;21(4):748-53.

5. Kagee A, Garcia del Soto A. Internal displacement and trauma: The need for a broader paradigm. Acta Geographica. 2003;Series A-6: 229-243

6. Salama P, Spiegel P, Brennan R. No less vulnerable: the internally displaced in humanitarian emergencies. Lancet. 2001;357:1430-1

7. Bhugra D, Jones P. Migration and mental illness, Adv Psychiatr Treat. 2001;7:216-222.

8. Porter M, Haslam N. Predisplacement and postdisplacement factors associated with mental health of refugees and internally displaced persons: a meta-analysis. JAMA. 2005 Aug 3;294(5):602-12.

9. Chukwuorji JBC, Ifeagwazi CM, Eze JE. Event centrality influences posttraumatic stress disorder symptoms via core beliefs in internally displaced older adults. Aging \& Mental Health. 2019;23:11321.

10. Silove $D$. The challenges facing mental health programs for post-conflict and refugee communities. Prehosp Disaster Med. 2004;19:90-6.

11. Thomas SL, Thomas SDM. Displacement and health. British Medical Bulletin. 2004; 69(1):115-127.

12. Almedom A, Tesfamichael B, Mohammed Z, Mascie-Taylor N, Muller J, Alemu Z. Prolonged displacement may compromise resilience in Eritrean mothers. African Health Sciences. 2005;5(4):310-14.

13. Bolton P, Wilk CM, Ndogoni L. Assessment of depression prevalence in rural Uganda using symptom and function criteria. Soc Psychiatry Psychiatr Epidemiol. 2004;39(6):442-7.

14. Cardozo BL, Bilukha OO, Crawford CAG, Shaikh I, Wolfe MI, Gerber ML, et al. Mental health, social functioning, and disability in postwar Afghanistan. JAMA. 2004;292(5):575-84.

15. Roberts B, Damundu EY, Lomoro O, Sondorp E. Post-conflict mental health needs: a cross-sectional survey of trauma, depression and associated factors in Juba, Southern Sudan. BMC Psychiatry. 2009;9:7.

16. Husain F, Anderson M, Cardozo BL, Becknell K, Blanton C, et al. (2011) Prevalence of war-related mental health conditions and association with displacement status in postwar Jaffna district, Sri Lanka. JAMA. 2011;306(5):522-33.

17. Makhashvili N, Javakhishvili J, Pinchuk I, Roberts B. Mental health conditions and co-morbidities among internally displaced populations (IDPs) in Ukraine. Eur Psychiatry. 2017;41:S245.

18. Bhugra D. Migration and mental health. Acta Psychiatr Scand. 2004;109(4):243-58.

19. Murthy RS, Lakshminarayana R. Mental health consequences of war: a brief review of research findings. World Psychiatry. 2006;5(1):25.

20. Siriwardhana C, Stewart R. Forced migration and mental health: prolonged internal displacement, return migration and resilience. International Health. 2013;5(1):19-23. 
21. Turnip SS, Hauff E. Household roles, poverty and psychological distress in internally displaced persons affected by violent conflicts in Indonesia. Soc Psychiatry Psychiatr Epidemiol. 2007;42:9971004.

22. Burns R, Wickramage K, Musah A, Siriwardhana C, Checchi F. Health status of returning refugees, internally displaced persons, and the host community in a post-conflict district in northern Sri Lanka: a cross-sectional survey. Confl Health. 2018;12:41.

23. ENSM Encuesta Nacional de Salud Mental: Colciencias, Ministerio de Salud y Protección Social y Pontificia Universidad Javeriana. 2015. https://www.javerianacali.edu.co/sites/ujc/files/node/fielddocuments/field_document_file/saludmental_final_tomoi_color.pdf. Accessed 20 Feb 2020.

24. ASIS Análisis de Situación de Salud con el Modelo de los Determinantes Sociales de Salud de Cesar: Secretaria de Salud Departamental del Cesar. 2016. https://www.minsalud.gov.co/sites/rid/Lists/BibliotecaDigital/Forms/DispForm.aspx?ID=16138. Accessed 20 Feb 2020.

25. PAPSIVI Protocolo de Atención Integral en Salud con enfoque psicosocial para las personas víctimas del conflicto armado en Colombia: Ministerio de Salud y Protección Social. 2013. https://www.minsalud.gov.co/proteccionsocial/Paginas/Victimas_PAPSIVI.aspx. Accessed 20 Feb 2020.

26. Shultz JM, Garfin DR, Espinel Z, Araya R, Oquendo MA, Wainberg ML, Chaskel R, Gaviria SL, Ordoñez AE, Espiñola M, Wilson FE, Muñoz N, Gomez AM, Garcia-Barcena Y, Verdeli H, Neria Y. Internally displaced 'victims of armed conflict' in Colombia: the trajectory and trauma signature of forced migration. Current Psychiatry Reports. 2014;16:475.

27. Santaella-Tenorio J, Bonilla-Escobar FJ, Nieto-Gil L, Fandiño-Losada A, Gutiérrez-Martínez MI, Bass J, Bolton P. Mental health and psychosocial problems and needs of violence survivors in the Colombian Pacific Coast: a qualitative study in Buenaventura and Quibdó. Prehospital and Disaster Medicine. 2018;33:567-574.

28. Wirtz AL, Pham K, Glass N, Loochkartt S, Kidane T, Cuspoca D, Rubenstein LS, Singh S, Vu A. Genderbased violence in conflict and displacement: qualitative findings from displaced women in Colombia. Conflict and Health. 2014;8:10.

29. Restrepo EM. Leaders against the odds: women victims of conflict in Colombia. Palgrave Communications. 2016;2:1-11.

30. RUV Registro Único de Victimas 2017-2018. https://www.unidadvictimas.gov.co/es/registrounico-devictimas-ruv/37394. Accessed 20 Feb 2020.

31. Gran Encuesta Integrada de Hogares: Dirección de Metodología y Producción Estadística (DIMPE). 2014. http://microdatos.dane.gov.co/index.php/catalog/68/study-description. Accessed 20 Feb 2020

32. Beusenberg M, Orley JH (editors). A User's guide to the self-reporting questionnaire (SRQ) WHO/MNH/PSF/94.8. 1994. Geneva: World Health Organization. 
33. Smilkstein G. The family APGAR: a proposal for a family function test and its use by physicians. $J$ Fam Pract. 1978;6:1231-9.

34. Freitag S, Braehler E, Schmidt S, Glaesmer H. The impact of forced displacement in world war II on mental health disorders and health related quality of life in late life- a German population-based study. International Psychogeriatrics. 2013;25:310-319.

35. Siriwardhana, C., Wickramage, K. Conflict, forced displacement and health in Sri Lanka: a review of the research landscape. Conflict and Health. 2014;8:22.

36. Sook LW, Sablihan NI, Ismail S, Devarai NK, Mooi CS. Factors associated with the level of physical activities among non-academic staffs in the Faculty of Medicine and Health Sciences of a public university in Selangor, Malaysia. Mal J Med Health Sci. 2019;15(2):47-55.

37. Lee KW, Ching SM, Hoo FK, Ramachandran V, Chong SC, Tusimin M, Nordin NM, Devaraj NK, Cheong AT, Chia YC. Neonatal outcomes and its association among gestational diabetes mellitus with and without depression, anxiety and stress symptoms in Malaysia: A cross-sectional study. Midwifery. 2020;81:102586.

38. Sistema Integral de Información (SISPRO) - Ministerio de Salud y Protección social (Minsalud): Reportes Salud mental. 2018. http://rssvr2.sispro.gov.co/ObsSaludMental/. Accessed 20 Feb 2020.

39. Campo-Arias A, Ceballos-Ospino GA, Herazo E. Barriers to access to mental health services among Colombia outpatients [published online ahead of print, 2020 May 28]. Int J Soc Psychiatry. 2020;20764020925105.

40. González LM, Penaloza RE, Matallana MA, Gil F, Gómez-Restrepo C, Vega Landaeta AP. Factores que determinan el acceso a servicios de salud mental de la población adulta en Colombia. Revista colombiana de psiquiatría. 2016;45(S1):89- 95.

41. Anaya Mercado DD, Romero Perez VP. Estrategias de afrontamiento en victimas desplazadas del corregimiento de El Salado, Bolivar in: Romero-Acosta K (edit.) Ocho estudios de salud mental. Cecar Editorial. 2019. DOI: 10.21892/978-958-5547-34-6.8

42. Gómez-Restrepo C, De Santacruz C, Rodriguez MN, Rodriguez V, Tamayo Martínez N, Matallana D, Gonzalez LM. Encuesta Nacional de Salud Mental Colombia 2015. Protocolo del estudio. Rev colomb psiquiat. 2016;45(S1):2-8.

43. Van der Westhuizen C, Wyatt G, Williams JK, Stein DJ, Sorsdahl K. Validation of the Self Reporting Questionnaire 20-Item (SRQ-20) for Use in a Low- and Middle-Income Country Emergency Centre Setting. Int J Ment Health Addict. 2016;14(1):37-48.

44. Chen S, Zhao G, Li L, Wang Y, Chiu H, Caine E. Psychometric properties of the Chinese version of the Self-Reporting Questionnaire 20 (SRQ-20) in community settings. Int J Soc Psychiatry. 2009; 55(6):538-47.

45. Patel V, Araya R, Chowdhary N, King M, Kirkwood B, Nayak S, Simon G, Weiss HA. Detecting common mental disorders in primary care in India: a comparison of five screening questionnaires. Psychol Med. 2008;38(2):221-8. 


\section{Figures}
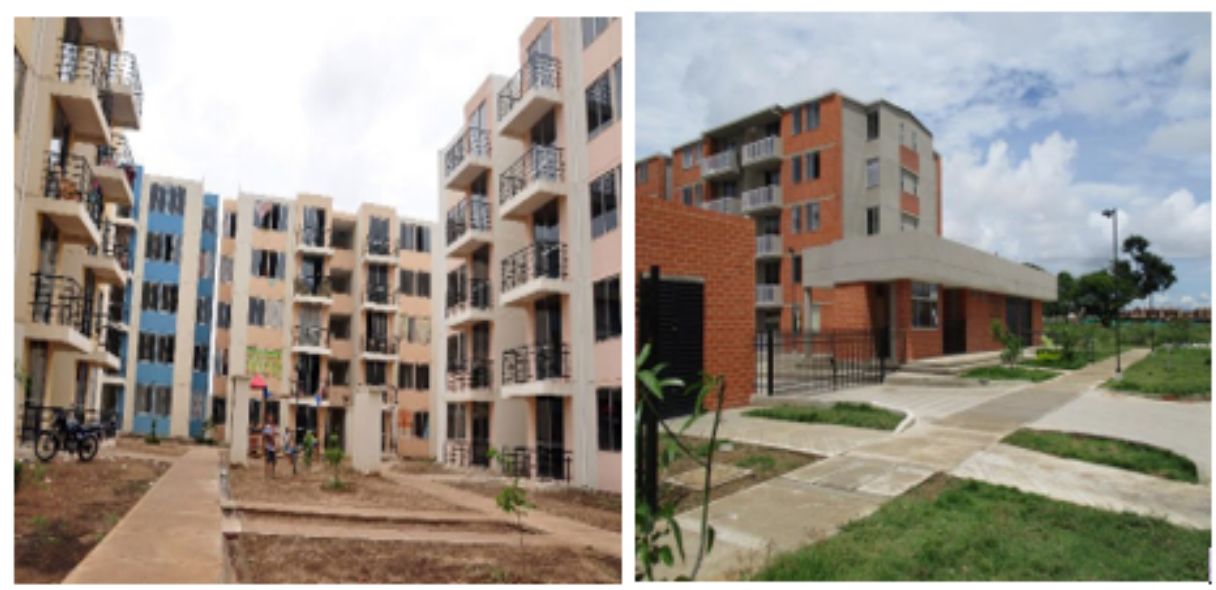

\section{Figure 1}

Compound of displaced families (left) and non-displaced families (right)

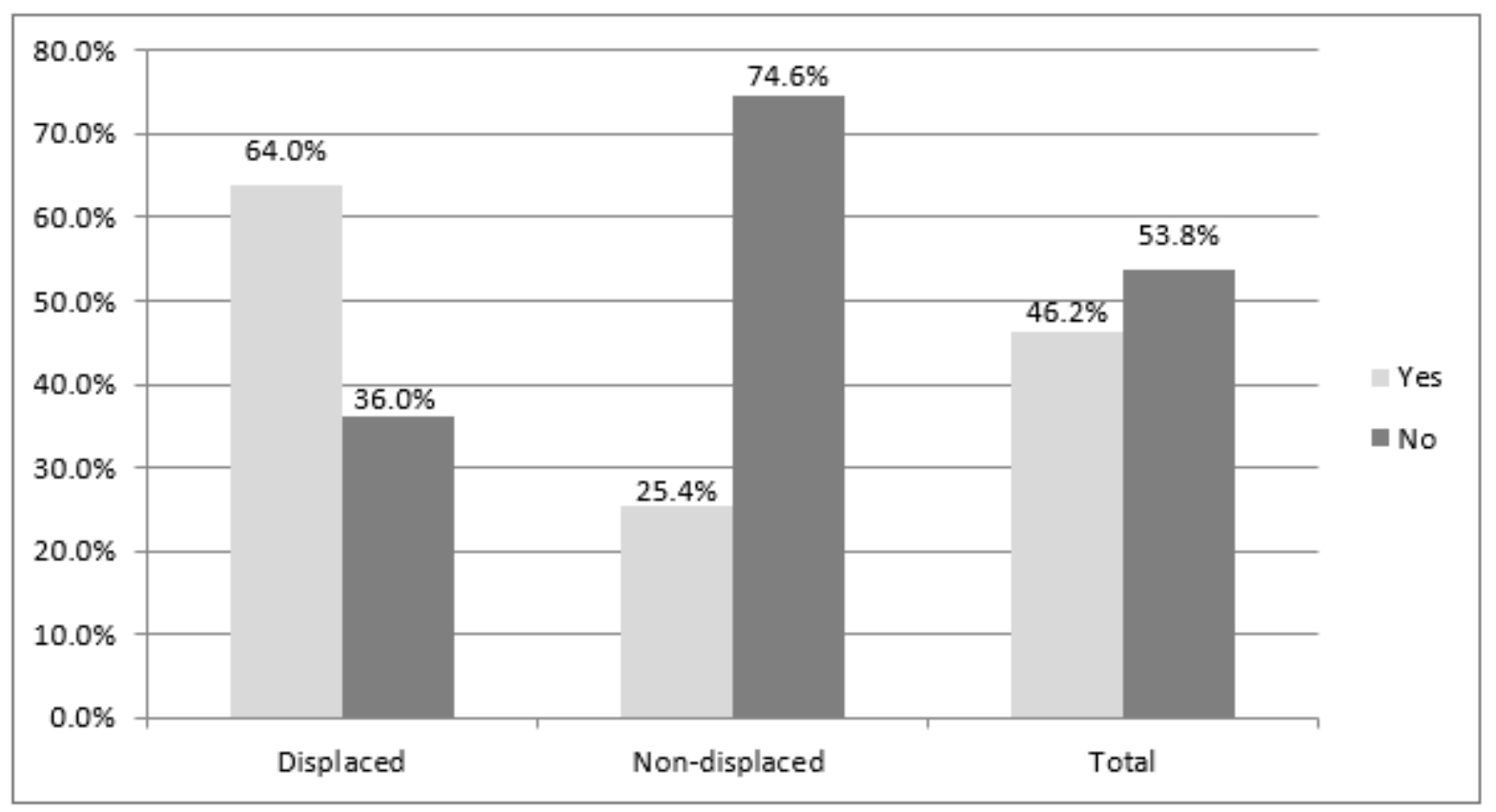

Figure 2

Victims of violence in displaced and non-displaced families. 


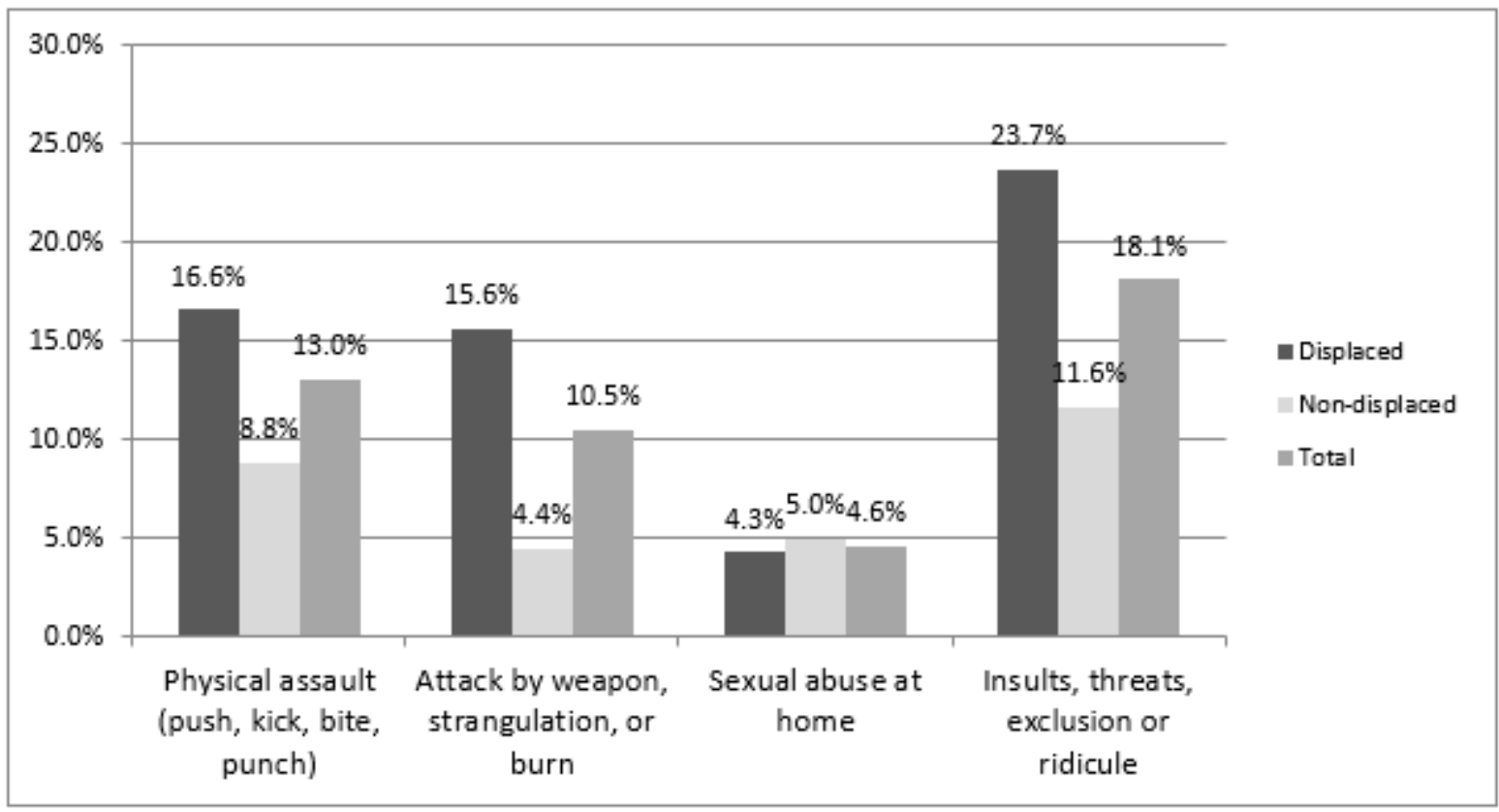

\section{Figure 3}

Intra-family violence among displaced and non-displaced families.

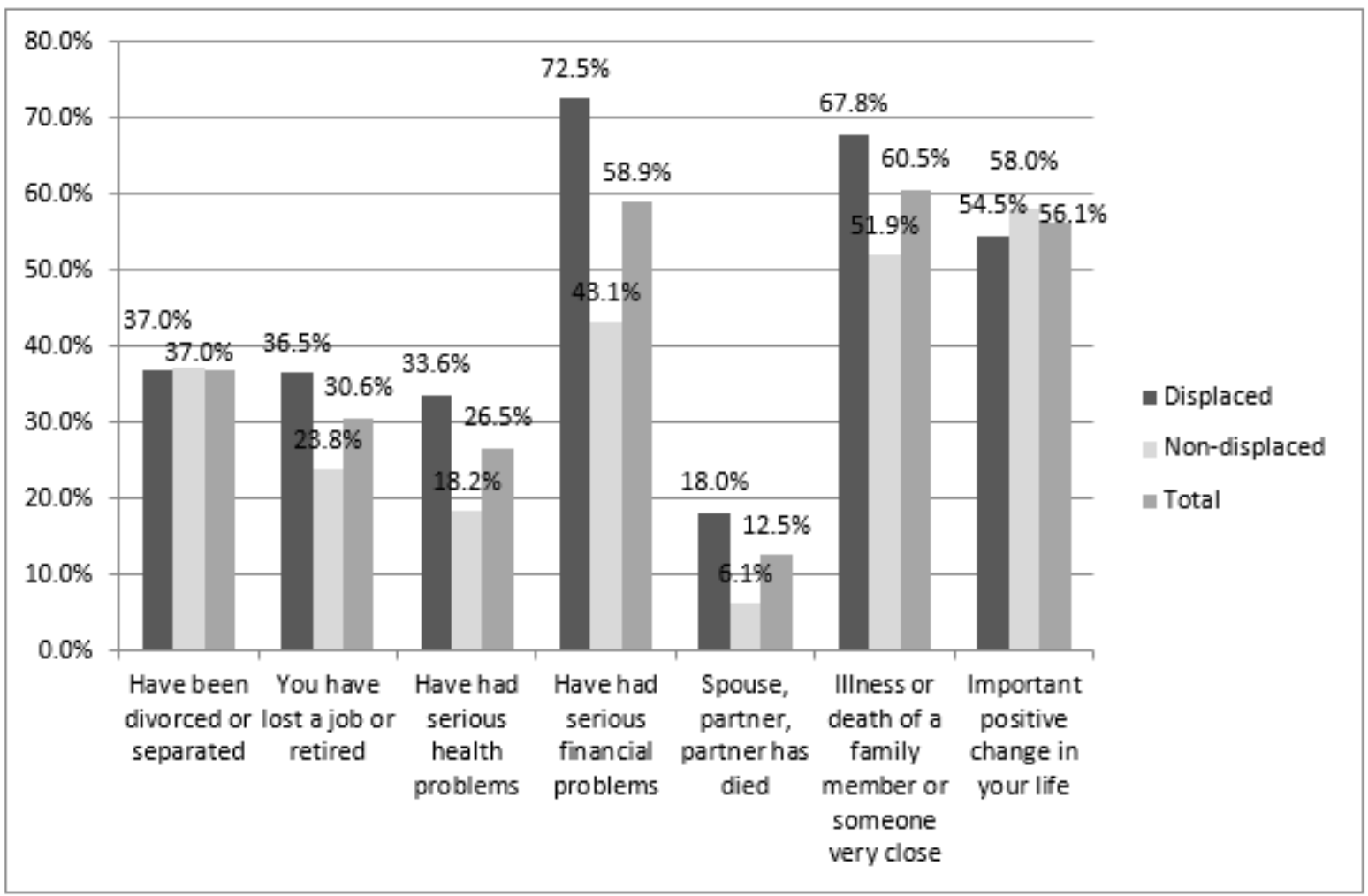

Figure 4

Life events among displaced and non-displaced families 


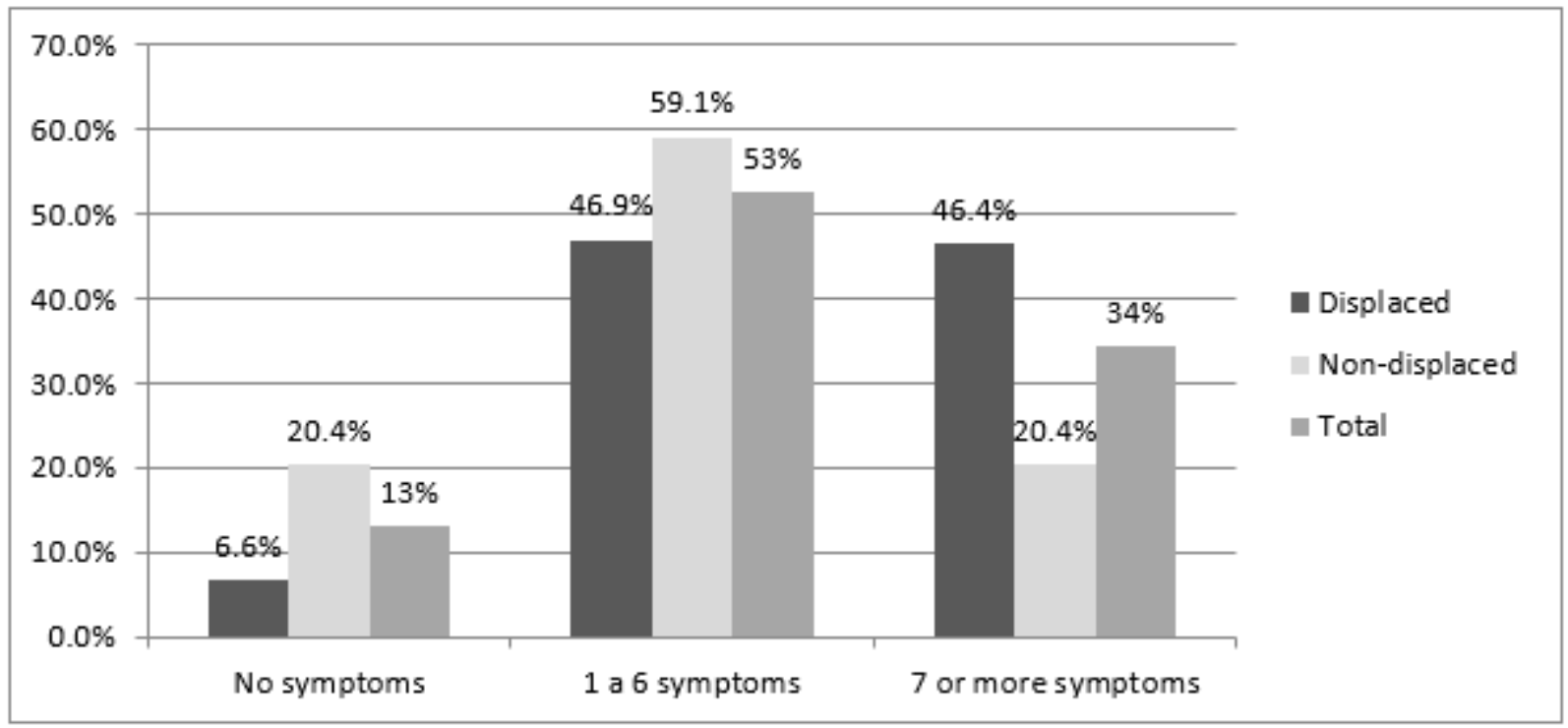

\section{Figure 5}

Number of emotional symptoms reported in the SRQ by formerly displaced and non-displaced individuals

\section{Supplementary Files}

This is a list of supplementary files associated with this preprint. Click to download.

- Additionalfile1.pdf 